University of Nebraska - Lincoln

DigitalCommons@University of Nebraska - Lincoln

Agronomy \& Horticulture -- Faculty Publications

Agronomy and Horticulture Department

2004

Resource Allocation in a Breeding Program for Phosphorus

Concentration in Maize Grain

Brandon M. Wardyn

lowa State Univ., Ames, IA

W. Ken Russell

University of Nebraska-Lincoln

Follow this and additional works at: https://digitalcommons.unl.edu/agronomyfacpub

Part of the Plant Sciences Commons

Wardyn, Brandon M. and Russell, W. Ken, "Resource Allocation in a Breeding Program for Phosphorus Concentration in Maize Grain" (2004). Agronomy \& Horticulture -- Faculty Publications. 309.

https://digitalcommons.unl.edu/agronomyfacpub/309

This Article is brought to you for free and open access by the Agronomy and Horticulture Department at DigitalCommons@University of Nebraska - Lincoln. It has been accepted for inclusion in Agronomy \& Horticulture -Faculty Publications by an authorized administrator of DigitalCommons@University of Nebraska - Lincoln. 


\title{
Resource Allocation in a Breeding Program for Phosphorus Concentration in Maize Grain
}

\author{
Brandon M. Wardyn* and W. Ken Russell
}

\begin{abstract}
When beef cattle (Bos taurus) are fed grain of maize (Zea mays L.) in which the concentration of phosphorus $(P)$ exceeds the animal's need for this element, the excess $P$ is excreted in the feces. Spreading this manure on cropland increases the potential for $P$ pollution of surface waters by run-off. Experiments were undertaken to determine the relative magnitudes of genotypic and nongenotypic variances of $P$ concentration in maize grain (P-Gr) to assess the ability to select maize genotypes in which this trait more closely matches the dietary need of beef cattle. Genetic variability was found in a population developed from a cross of Illinois High Protein $($ IHP) $\times$ Illinois Low Protein (ILP). Because of few low P-Gr segregates, the IHP $\times$ ILP population was not considered a good breeding source for this trait. Nongenetic sources of variance were significant but small compared with genotypic variances. Broad-sense heritability $(H)$ for $\mathbf{P}-\mathbf{G r}$ among $S_{1}$ family means in the IHP $\times$ ILP population was estimated at 0.82 . This high value suggested that this trait would respond to selection. A comparison of mean values of $S_{1}$ families selected on the basis of performance in 2000 or in 2001 alone to those selected on the basis of 2-yr data suggested that the loss in efficiency resulting from selecting on 1-yr data would be only approximately $5 \%$.
\end{abstract}

$\mathrm{M}$ AIZE IS THE PRIMARY GRAIN used in the diets of many livestock animals in the USA. Because the grain of maize is approximately $75 \%$ starch and primarily is used as a source of energy, maize-based diets frequently are supplemented with nutrients. In the case of monogastric animals, the need to add $\mathrm{P}$ is not an insufficient amount of this element in maize grain per se, but rather because $80 \%$ of the $\mathrm{P}$ in maize grain is in the form of phytate (Raboy, 1997). Monogastric animals lack a sufficient quantity of the intestinal enzyme phytase, which cleaves $\mathrm{P}$ from phytate, to access much of the $\mathrm{P}$ from maize grain. In the guts of ruminants, such as cattle, microbes produce phytase. All phytate $\mathrm{P}$ was released when incubated with rumen fluid (Morse et al., 1992), so all organic $P$ is thought to be available to cattle (Council for Agricultural Science and Technology, 2002).

On the basis of analyses at commercial laboratories in the USA and Canada, maize grain contains $0.32 \% \mathrm{P}$ (National Research Council, 1996). Wet gluten feed, steep liquor, and wet distiller grains, which are by-products of wet- or dry-milling of maize that often are added

B.M. Wardyn, Dep. of Agronomy, Iowa State Univ., Ames, IA 50011; W.K. Russell, Dep. of Agronomy and Horticulture, 279 Plant Science Bldg., Univ. of Nebraska-Lincoln, Lincoln, NE 68583-0915. Journal Series No. 4002 of the Univ. of Nebraska, Agricultural Research Division. This study was funded by a grant from the Nebraska Corn Board. Received 9 March 2003. *Corresponding author (bmwardyn@ iastate.edu).

Published in Crop Sci. 44:753-757 (2004). to feedlot rations of beef cattle, have $\mathrm{P}$ concentrations that are at least two to four times as high as in whole grain (Milton, 2000). The National Research Council (1996) recommended a $\mathrm{P}$ intake by beef cattle of 0.20 to $0.30 \% \mathrm{P}$, assuming a daily feed intake of 9 to $11 \mathrm{~kg}$. However, Erickson et al. (1999) found that the P requirement of finishing yearlings was $0.14 \%$ or less. Other feeding trials indicated that the National Research Council guidelines over-predicted by at least $25 \%$ the need of yearlings (Erickson et al., 2002) and of developing heifers (Call et al., 1978) for P.

Excess amounts of $\mathrm{P}$ that are ingested by cattle are excreted largely in the feces. When manure from feedlots is continually spread on adjacent cropland, levels of $\mathrm{P}$ in the soil often become much higher than needed for crop production. Runoff from soils that are high in $\mathrm{P}$ is a major cause of eutrophication in surface waters (Duda and Finan, 1983). Traditionally, application rates for cattle manure on cropland have been calculated by matching the nitrogen content of the manure to the nitrogen requirement of the intended crop, which often is maize. Maize plants use nitrogen and phosphorus in an 8:1 ratio; however, in cattle manure these elements typically are in a 4:1 ratio (White and Collins, 1982). The EPA (2002) now requires implementation of a sitespecific nutrient management plan for all concentrated animal feeding operations. Regulatory changes that specify application rates of manure to cropland be based on existing soil nutrient levels and the nutrient needs of the intended crop are being proposed.

One remedy for reducing the potential of $\mathrm{P}$ pollution from beef cattle feedlots is to spread the manure over more hectares of cropland. This approach, however, adds costs. Another potential remedy is to reduce the $\mathrm{P}-\mathrm{Gr}$ in maize to a level that more closely matches the dietary need of beef cattle for this element. Commercial maize breeders in the USA do not commonly use P-Gr as a selection criterion. Vyn and Tollenaar (1998) evaluated six commercial maize hybrids with release dates from 1959 to 1988. Although grain yield increased, P-Gr was unchanged. Two mutants of maize, lpa2-1 and lpal-1, have been reported that reduce the phytate content in the grain by 50 to $60 \%$ (Ertl et al., 1998). However, these mutants do not affect P-Gr.

Little information is available on the inheritance of P-Gr. There is some evidence for genetic variation for this trait. Raboy et al. (1989) reported nearly a two-fold difference in P-Gr between the 83rd cycles of the divergently selected populations, IHP and ILP (Dudley and Lambert, 1992). Feil et al. (1992) found a significant dif-

Abbreviations: BLUP, best linear unbiased predictor; $H$, broad-sense heritability; $h^{2}$, narrow-sense heritability; IHP, Illinois High Protein; ILP, Illinois Low Protein; P-Gr, phosphorus concentration in grain. 
ference in P-Gr between two tropical maize hybrids across multiple rates of application of N. In addition to sources of genetic variability, plant breeders use estimates of heritability and information on the relative magnitudes of genetic, genetic $\times$ environmental, and error variances to optimize allocation of resources in a field-based selection program. Obtaining estimates of these genetic parameters in a maize population known to be highly variable for P-Gr was the objective of this study.

\section{MATERIALS AND METHODS}

The genetic material was 200 random $S_{1}$ families that were developed from a population formed by crossing the 70th cycles of the IHP and ILP populations. Approximately six plants of each parental population were crossed to form the F1, which was then selfed to form the F2 generation. The F2 was random-mated for two generations. Seed of both the $F_{1}$ and sibbed $\mathrm{F}_{2}$ generations was produced by John Dudley at the University of Illinois. Prior research (Raboy et al., 1989) suggested that genetic variability would exist in this population for P-Gr. Thus, the random S1 families were expected to be appropriate genetic material with which to estimate the relative magnitudes of genetic, genetic $\times$ environmental, and error variances for this trait.

The $S_{1}$ families were evaluated for P-Gr in the same field on the campus of the University of Nebraska-Lincoln in 2000 and 2001, using a different area of the field each year. Inbreds B73, FR1064, and Mo17 were included as checks in 2001 only. The soil type was a Kennebec silt loam, and in both years the previous crop was soybeans [Glycine $\max$ (L.) Merr.]. Plots were watered as frequently as weekly from mid-June to late August to minimize visible drought stress. Soil $\mathrm{P}$ concentration was determined before planting in 2000 and 2001 by collecting and mixing 10 random soil samples from the plot area at a depth of 5 to $15 \mathrm{~cm}$ and then using the Bray-1 extraction method. Each year, $202 \mathrm{~kg} \mathrm{ha}^{-1}$ of $\mathrm{N}$ was applied approximately three weeks before planting in the form of anhydrous ammonia. Plot row length was $3.8 \mathrm{~m}$. All plots were overplanted and then thinned to a final population of 55100 plants ha $^{-1}$ in 2000 and 51600 plants ha ${ }^{-1}$ in 2001.

\section{P-Gr Determination}

Values of P-Gr were determined on grain samples obtained from hand-pollinated ears that were harvested shortly after physiological maturity (black-layer formation), dried at $32^{\circ} \mathrm{C}$ for a week, and then shelled by hand. Moldy kernels or kernels with insect damage were discarded. Also, any ears with less than 50 competitive kernels were not used. A composite grain sample was produced from each field plot by randomly sampling approximately 20 kernels from each of three to five sib-pollinated ears. Different plants were used as males and females, so a minimum of six plants per plot was sampled. For inbreds B73 and FR1064, multiple P-Gr determinations were made per plot in addition to the single determination from the composite grain sample. In each plot of these inbreds, two independent samples were obtained from each of two random ears produced by sib-mating. All grain samples were ground until $97 \%$ of the sample could pass through a $1.18-\mathrm{mm}$ screen. Phosphorus analyses were conducted at the University of Nebraska-Lincoln Soil and Plant Analytical Laboratory with a Tracor (Austin, TX, USA) Spectrace 5000 (energy dispersive X-ray fluorescence method).

\section{Field Design and Statistical Analysis}

In 2000, $180 \mathrm{~S}_{1}$ families were evaluated by an $\alpha$ design with 15 families per block, 12 blocks per replication, and two replications. In 2001, the same $180 \mathrm{~S}_{1}$ families and 20 additional $\mathrm{S}_{1}$ families were evaluated by a sets-in-replication design with 20 unique families and the three inbred checks per set and two replications. Because different field designs were used each year, an analysis of the 2001 data (checks included) was done first by PROC GLM (SAS Institute Inc., 1999) to obtain $\mathrm{S}_{1}$ family $\times$ replication least-squared means. This procedure adjusted for the set effects. These adjusted means, minus the checks, were then combined with the 2000 data in an acrossyears analysis to obtain estimates of the year variance $\left(\sigma_{Y}^{2}\right)$, the genetic variance among $\mathrm{S}_{1}$ families $\left(\sigma_{F}^{2}\right)$, the family $\times$ year interaction variance $\left(\sigma_{F Y}^{2}\right)$, and the residual variance $\left(\sigma_{e}^{2}\right)$ by the likelihood statistical methods of PROC MIXED (Littell et al., 1996). Also, the best linear unbiased predictor (BLUP) of the P-Gr value of each $\mathrm{S}_{1}$ family was calculated.

The residual variance from the analysis of $S_{1}$ family plot values was equal to

$$
\sigma_{e^{\prime}}^{2}+\frac{\sigma_{w(\text { env })}^{2}}{n}+\frac{\sigma_{w(\text { gen })}^{2}}{n}+\frac{\sigma_{s}^{2}}{n s}, \text { where }
$$

$\sigma_{e^{\prime}}^{2}=$ between-plot error variance, $\sigma_{w(\text { env })}=$ within-plot environmental variance, $\sigma_{w(\text { gen })}^{2}=$ within-plot genetic variance, $\sigma_{s}^{2}=$ sampling variance within ears, $n=$ number of ears sampled per plot, and $s=$ number of samples per ear.

Assuming inbreds B73 and FR1064 were completely homozygous, estimates of $\sigma_{s}^{2}$ and $\sigma_{w(\text { env })}^{2}$ were obtained directly from analysis of the within-plot sampling of these inbreds because the value of $\sigma_{w(\mathrm{gen})}^{2}$ was 0 . In the analysis of the $S_{1}$ families, $\sigma_{w(\text { gen })}^{2}$ equaled $\sigma_{w\left(\mathrm{~S}_{1}\right)}^{2}$, which was not expected to equal 0 . Assuming that the values of $\sigma_{e^{\prime}}^{2}, \sigma_{w(\text { env })}^{2}$, and $\sigma_{s}^{2}$ were the same for the $\mathrm{S}_{1}$ families and the inbreds, then an estimate of $\sigma_{w\left(\mathrm{~S}_{1}\right)}^{2}$ was

$$
n^{\prime}\left[\hat{\sigma}_{e}^{2}-\hat{\sigma}_{e^{\prime}}^{2}-\frac{\hat{\sigma}_{w(\mathrm{env})}^{2}}{n^{\prime}}-\frac{\hat{\sigma}_{s}^{2}}{n^{\prime} s^{\prime}}\right], \text { where }
$$

$n^{\prime}=4.7$, the average number of ears sampled per $\mathrm{S}_{1}$ family in this experiment and $s^{\prime}=1.0$, the number of samples per ear in this experiment. The significance of $\hat{\sigma}_{Y}^{2}, \hat{\sigma}_{F}^{2}, \hat{\sigma}_{F Y}^{2}, \hat{\sigma}_{e^{\prime}}^{2}$ and $\hat{\sigma}_{w(\text { env) }}^{2}$ was tested by the likelihood ratio statistic (Littell et al., 1996). The significance of the other estimates of variance components could not be tested with this statistic.

Broad-sense heritability $(H)$ on a $\mathrm{S}_{1}$ family mean basis was estimated by the formula,

$$
\hat{H}_{\overline{\mathrm{S}}_{1}}=\frac{\hat{\sigma}_{F}^{2}}{\hat{\sigma}_{F}^{2}+\frac{\hat{\sigma}_{F Y}^{2}}{y}+\frac{\hat{\sigma}_{e^{\prime}}^{2}}{y r}+\frac{\hat{\sigma}_{w(\text { env })}^{2}}{y r n}+\frac{\hat{\sigma}_{w\left(\mathrm{~S}_{1}\right)}^{2}+\frac{\hat{\sigma}_{s}^{2}}{y r n}}{y r n s}} \text {, where }
$$

$y=$ number of years and $r=$ number of replications per year. The denominator in this equation is an estimate of the phenotypic variance among $\mathrm{S}_{1}$ family means $\left(\hat{\sigma}_{P}^{2}\left(\overline{\mathrm{S}}_{1}\right)\right)$. The values of $\hat{\sigma}_{P\left(\overline{\mathrm{S}}_{1}\right)}^{2}$, and of $H_{\overline{\mathrm{S}}_{1}}$, depend on the values of $y, r, n$, and $s$. Once estimates of the variance components for $\hat{\sigma}_{P}^{2}\left(\bar{S}_{1}\right)$ were obtained, then the effect of varying the values of $y, r, n$, and $s$ on $\hat{H}_{\overline{\mathrm{S}}_{1}}$ was determined.

\section{RESULTS AND DISCUSSION}

The soil $\mathrm{P}$ readings were 71 and $38 \mu \mathrm{g} \mathrm{g}^{-1}$ in 2000 and 2001, respectively. Such a large difference was not expected; although the experiment was grown in different parts of the same field in the two years, the soil type 
was the same and neither $\mathrm{P}$ fertilizer nor manure was applied to the field during either year.

In the analysis of the $S_{1}$ families, the year effect was significant $(p<0.05)$, whereas the family and family $\times$ year interaction were highly significant $(p<0.01)$ (Table 1). The year means of the $177 \mathrm{~S}_{1}$ families for which data were obtained in both years were $3.6 \mathrm{~g} \mathrm{~kg}^{-1}$ in 2000 and $3.2 \mathrm{~g} \mathrm{~kg}^{-1}$ in 2001. The relative values of these year means of P-Gr were consistent with the soil $\mathrm{P}$ readings; that is, the higher $\mathrm{P}-\mathrm{Gr}$ mean was obtained in the year of the higher soil $\mathrm{P}$ reading.

The BLUP values of the $\mathrm{S}_{1}$ family means for $\mathrm{P}-\mathrm{Gr}$ ranged from 2.2 to $4.8 \mathrm{~g} \mathrm{~kg}^{-1}$, and the distribution of these values did not differ significantly from normality (Fig. 1). Assuming a desirable level of P-Gr of $1.4 \mathrm{~g}$ $\mathrm{kg}^{-1}$ (Erickson et al., 1999), the value of P-Gr of the lowest $S_{1}$ was nearly three standard deviations greater than this level. Even relative to the inbred checks, only eight of the $S_{1}$ families had BLUP values less than the mean of the lowest check inbred (Mo17, $2.7 \mathrm{~g} \mathrm{~kg}^{-1}$ ), whereas 50 had BLUP values greater than the mean of the highest inbred (FR1064, $3.5 \mathrm{~g} \mathrm{~kg}^{-1}$ ). Thus, even though highly significant genetic variation existed in this population for P-Gr, the low frequency of segregates with low P-Gr values indicated that several cycles of selection for low P-Gr likely would be needed before this population would be a good source from which to extract inbreds with a near desirable level of P-Gr. Other characteristics limiting the usefulness of this population as a breeding source were lodging susceptibility and poor stress tolerance.

Although the estimate of $\sigma_{F Y}^{2}$ was highly significant, it was only $18 \%$ as large as the estimate of $\sigma_{F}^{2}$. Of the
Table 1. Estimates of variance components for $P$ concentration in maize grain (P-Gr). Data are from evaluation of 200 random $S_{1}$ families developed from the $F_{2}$ sib-mated generation of the cross between the Illinois High Protein (IHP) and Illinois Low Protein (ILP) populations in 2000 and 2001 and from evaluation of two inbreds in 2001.

\begin{tabular}{lcc}
\hline Variance component & Estimate & Prob $\dagger$ \\
\hline & $\left(\mathrm{g} \mathrm{kg}^{-1}\right)^{2} \times \mathbf{1 0}^{-2}$ & \\
From evaluation of $\mathrm{S}_{1}$ families & & \\
$\quad$ Year & $\mathbf{8 . 5}$ & $\mathbf{0 . 0 4}$ \\
Family & $\mathbf{3 4 . 0}$ & $<\mathbf{0 . 0 1}$ \\
Family $\times$ Year & $\mathbf{6 . 2}$ & $<\mathbf{0 . 0 1}$ \\
$\quad$ Residual & $\mathbf{1 7 . 7}$ & \\
From evaluation of two inbreds & 3.5 & $<0.01$ \\
$\quad$ Between-plot error & $\mathbf{7 . 6}$ & $<0.01$ \\
$\quad$ Within-plot environmental & $\mathbf{1 . 3}$ & \\
Sampling & \\
\hline
\end{tabular}

$\dagger$ Probability of a Chi-square value being greater than the log likelihood statistic (Littell et al., 1996).

$18 \mathrm{~S}_{1}$ families (10\% of the $177 \mathrm{~S}_{1}$ 's evaluated both years) with the lowest 2-yr average values of $\mathrm{P}-\mathrm{Gr}, 13$ were in the top $10 \%$ in 2000 and a slightly different set of 13 were in the top $10 \%$ in 2001 (Table 2). Only one and two of these best $18 \mathrm{~S}_{1}$ families were not in the top $20 \%$ in 2000 and 2001, respectively. On the basis of 2-yr data and a $10 \%$ selection intensity, the selection differentials (the difference of the means of the selected families and of all families over both years) for selection based on 2000 results alone, 2001 results alone, and 2000 to 2001 combined results were $0.10,0.09$, and 0.10 . Thus, the presence of family $\times$ year interaction caused the selection differential based on 1-yr data to be on average only $5 \%$ less than the selection differential based on 2-yr data.

From analysis of the B73 and FR1064 data, estimates

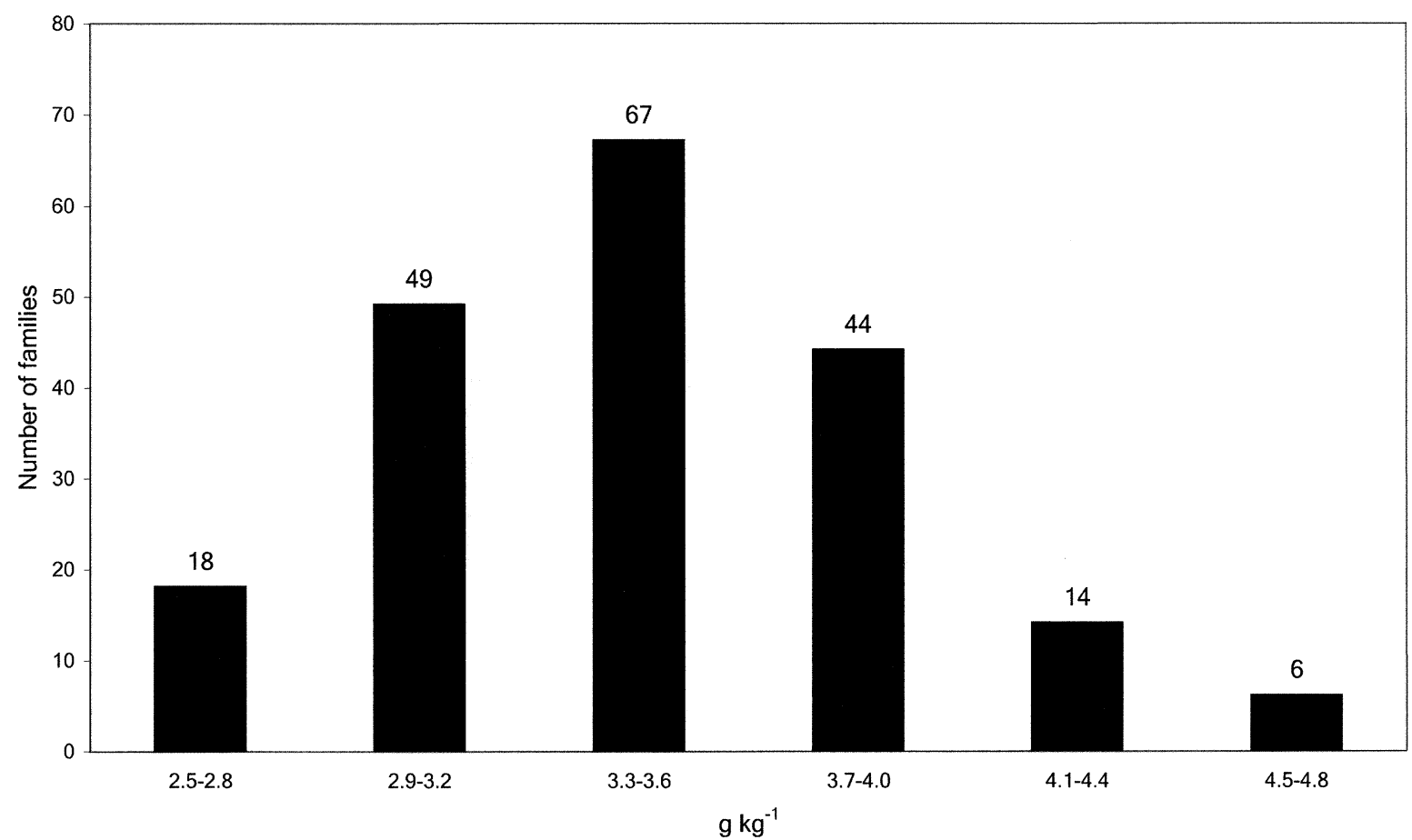

Fig. 1. Distribution of $S_{1}$ family BLUP (best linear unbiased predictor) values for $P$ concentration in maize grain (P-Gr) across 2000 and 2001. The $S_{1}$ families were randomly generated from the $F_{2}$ sibbed generation of the cross between the Illinois High Protein and Illinois Low Protein populations. 
Table 2. Rankings and means for phosphorus concentration in the grain (P-Gr) of the best $18($ top $10 \%) S_{1}$ families based on 2-yr data (2000-2001) and for each year separately. The $S_{1}$ families were random families from the $F_{2}$ sib-mated generation of the cross between the Illinois High Protein (IHP) and Illinois Low Protein (ILP) populations.

\begin{tabular}{|c|c|c|c|c|c|c|}
\hline \multirow[b]{2}{*}{ Family } & \multicolumn{2}{|c|}{ 2000-2001 } & \multicolumn{2}{|c|}{2000} & \multicolumn{2}{|c|}{2001} \\
\hline & Rank & P-Gr & Rank & P-Gr & Rank & P-Gr \\
\hline & & $\mathrm{g} \mathrm{kg}^{-1}$ & & $\mathrm{~g} \mathrm{~kg}^{-1}$ & & $\mathrm{~g} \mathrm{~kg}^{-1}$ \\
\hline 112 & 1 & 1.96 & 2 & 2.12 & 4 & 1.79 \\
\hline 118 & 2 & 2.00 & 5 & 2.32 & 2 & 1.68 \\
\hline 13 & 3 & 2.14 & 15 & 2.67 & 1 & 1.61 \\
\hline 110 & 4 & 2.17 & 9 & 2.50 & 5 & 1.84 \\
\hline 26 & 5 & 2.20 & 16 & 2.71 & 3 & 1.70 \\
\hline 60 & 6 & 2.27 & 7 & 2.43 & 7 & 2.12 \\
\hline 166 & 7 & 2.28 & 1 & 1.88 & 44 & 2.67 \\
\hline 91 & 8 & 2.38 & 11 & 2.60 & 8 & 2.16 \\
\hline 96 & 9 & 2.42 & 4 & 2.31 & 28 & 2.53 \\
\hline 66 & 10 & 2.50 & 12 & 2.61 & 14 & 2.40 \\
\hline 159 & 11 & 2.52 & 10 & 2.58 & 22 & 2.46 \\
\hline 31 & 12 & 2.54 & 21 & 2.82 & 13 & 2.27 \\
\hline 86 & 13 & 2.57 & 50 & 3.26 & 6 & 1.88 \\
\hline 57 & 14 & 2.57 & 17 & 2.72 & 17 & 2.42 \\
\hline 178 & 15 & 2.60 & 6 & 2.42 & 51 & 2.78 \\
\hline 151 & 16 & 2.61 & 31 & 2.98 & 10 & 2.24 \\
\hline 165 & 17 & 2.62 & 35 & 3.04 & 9 & 2.20 \\
\hline 46 & 18 & 2.65 & 20 & 2.79 & 24 & 2.50 \\
\hline Std. err. & & 0.27 & & 0.30 & & 0.30 \\
\hline
\end{tabular}

of $\sigma_{e^{\prime}}^{2}$ and $\sigma_{w(\text { env })}^{2}$ were significantly greater than 0.0 (Table 1). The estimate of $\sigma_{s}^{2}$ was less than one-half the value of $\hat{\sigma}_{e^{\prime}}^{2}$, whereas the estimate of $\sigma_{w(\text { env })}^{2}$ was more than twice $\hat{\sigma}_{e^{\prime}}^{2}$. The estimate of $\left.\sigma_{w}^{2}{\overline{S_{s}}}_{1}\right)$ was $57.8 \times 10^{-2}(\mathrm{~g}$ $\left.\mathrm{kg}^{-1}\right)^{2}$. These variance estimates were obtained from 2001 data only, but the similarity of the estimates of $\sigma_{e}^{2}$ from each year $\left[18.0 \times 10^{-2}\right.$ and $17.4 \times 10^{-2}\left(\mathrm{~g} \mathrm{~kg}^{-1}\right)^{2}$ in 2000 and 2001, respectively] suggested that estimates obtained from combined data over both years would be similar.

The estimate of $\hat{H}_{\overline{\mathrm{S}}_{1}}$ was 0.82 , which provided a measure of the relative importance of genetic and environ- mental effects. In an intra-population selection program, such as recombining $S_{1}$ families with the lowest $\mathrm{P}-\mathrm{Gr}$ values, only additive genetic variance reflects useable genetic variance. Therefore, this estimate of broadsense heritability overestimates the percentage of the selection differential that would be retained in a cycle of selection. Nonetheless, the closeness of $\hat{H}_{\bar{S}_{1}}$ to 1.0 certainly suggested that P-Gr could be easily modified in this population of $S_{1}$ families by selection. The large value of this estimate is similar to estimates of narrowsense heritability $\left(h^{2}\right)$ as high as 0.60 that have been reported for other kernel components in maize ( $\mathrm{Zehr}$ et al., 1996). Also, the large value of $\hat{H}_{\overline{\mathrm{S}}_{1}}$ was consistent with the finding of Wardyn (2001) that $S_{0}$ genotypes that were rated as being either low or high for P-Gr based on analysis of grain from a single, self-pollinated ear, responded similarly when evaluated as $\mathrm{S}_{1}$ progenies in a subsequent year.

The total within-plot variance is the sum of $\sigma_{w(\text { env })}^{2}$, $\sigma_{w\left(\bar{S}_{1}\right)}^{2}$, and $\sigma_{s}^{2}$. The greater the value of $n$, the less is the contribution of the within-plot variance to $\hat{\sigma}_{P}^{2}\left(\overline{\mathrm{S}}_{1}\right)$. For given values of $y$ and $r$, the maximum value of $\hat{H}_{\overline{\mathrm{S}}_{1}}$ occurs as $n \rightarrow \infty$. The estimates of the variance components of $\hat{\sigma}_{P\left(\bar{S}_{1}\right)}^{2}$ obtained in this research indicated that with $y=$ 2 and $r=2$ the maximum value of $\hat{H}_{\overline{\mathrm{S}}_{1}}$ was 0.90 . Over $90 \%$ of this maximum value (i.e., $\hat{H}_{\overline{\mathrm{S}}_{1}}=0.82$ ) was realized with $n=4.7$. Increasing $n$ by a factor of two to 9.4 would have increased $\hat{H}_{\bar{S}_{1}}$ to only 0.86 (Fig. 2). In contrast, increasing $n$ from 1 to 4.7 , increased $\hat{H}_{\overline{\mathrm{S}}_{1}}$ from 0.63 to 0.82 . The greatest effect on $\hat{H}_{\overline{\mathrm{S}}_{1}}$ of increasing $n$ occurred when $y=r=1$. Even in that situation, however, the effect of doubling $n$ from 5 to 10 was an increase in $\hat{H}_{\bar{S}_{1}}$ from only 0.60 to 0.68 . On a proportionality basis, the same effect of increasing $n$ would occur for $h^{2}$, because the denominator is the same for both $\hat{H}_{\bar{S}_{1}}$ and $h^{2}$. Thus, these data suggested that little gain in efficiency

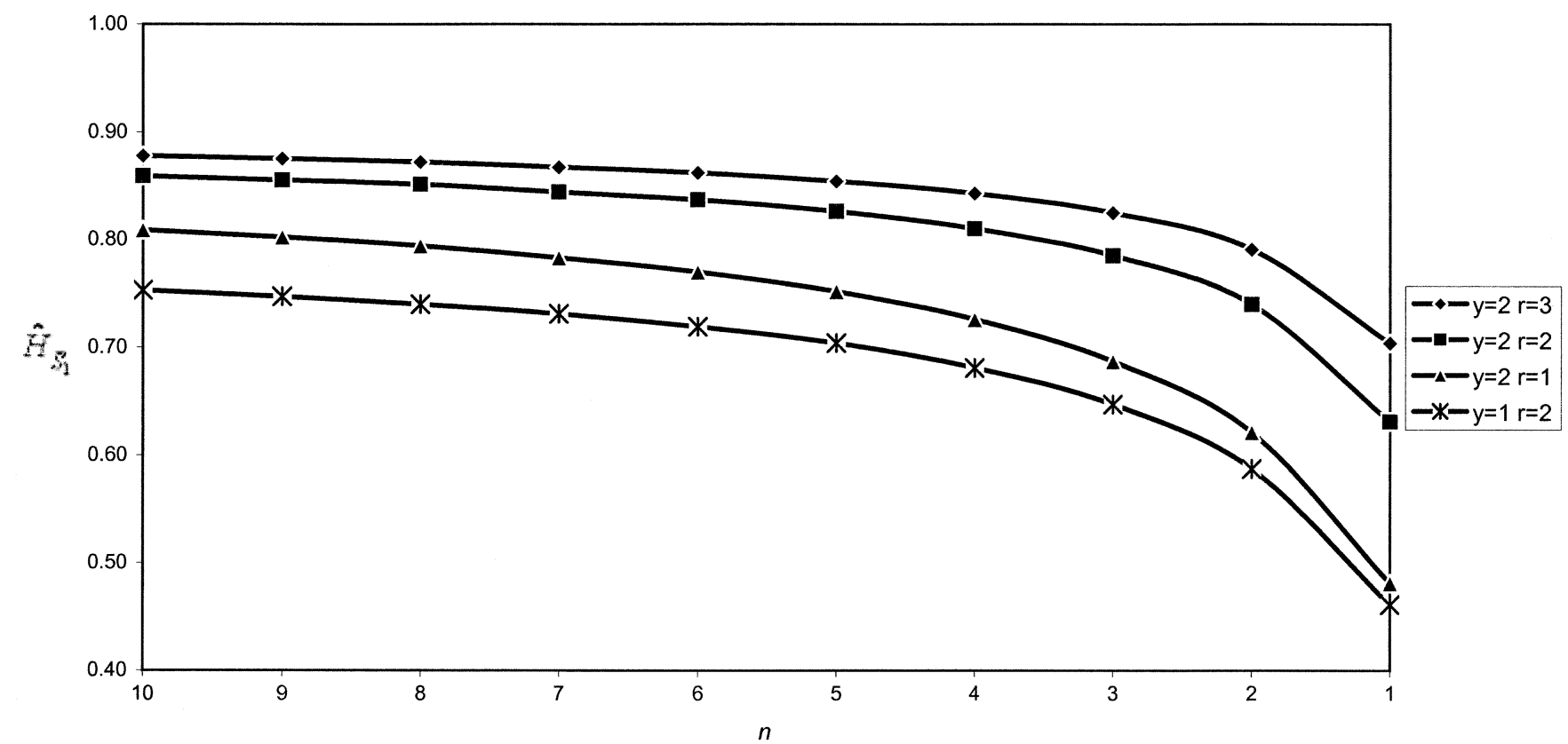

Fig. 2. Effects of number of years $(y)$, replications per year $(r)$, and ears sampled per plot $(n)$ on the broad-sense heritability among $S_{1}$ family means $\hat{H}_{\overline{\mathrm{S}}_{1}}$ for $\mathbf{P}$ concentration in maize grain. 
of selection for P-Gr would be realized by sampling more than five, sib-pollinated ears per plot.

The lines in Fig. 2 also provide a comparison of different allocation of resources to $y$ and $r$. The total number of replications is two for both $y=2, r=1$, and $y=1$, $r=2$. The first of these allocations will always result in a greater value of $\hat{H}_{\bar{S}_{1}}$, because $y$ is a divisor for $\sigma_{F Y}^{2}$ whereas $r$ is not. At $n=5$, the values of $\hat{H}_{\bar{S}_{1}}$ were 0.75 and 0.70 for $y=2, r=1$, and $y=1, r=2$, respectively. However, increasing $y$ from 1 to 2 in a selection program would reduce expected gain per year by a half. Thus, these results suggested that in a selection program $y=$ $1, r=2$ would be a better allocation of resources than $y=2, r=1$, even though the latter gave a higher value of $\hat{H}_{\overline{\mathrm{s}}_{1}}$. The genotypic $\times$ location variance was not estimated in this research, but replacing replications with locations would be reasonable if the value of this variance was found to be greater than the value of $\sigma_{e}^{2}$.

All the sampled ears in this research were produced from hand-pollinations. This was done because the effect of pollen source on P-Gr was unknown. Because of the time and cost involved in making hand-pollinations, the effect of pollen source on $\mathrm{P}-\mathrm{Gr}$ is an issue that should be investigated. Wardyn (2001) observed in a single-environment experiment that the effect of pollen source on P-Gr was minor. If this result is substantiated in additional environments, then grain from the same number of open-pollinated versus hand-pollinated ears could be used to determine P-Gr with little loss in selection gain. If, for example, the effect of the pollen source was $10 \%$, then in a selection program with $y=$ $1, r=2$ sampling 10 open-pollinated ears or five sibpollinated ears would give approximately the same selection gain (Fig. 2).

In summary, the results of this research indicated that in the population developed from the cross of IHP and ILP that P-Gr is a highly heritable trait should be responsive to selection. Because $\mathrm{P}$ is an essential element for plant growth, there likely is a lower biological limit for P-Gr that is greater than 0.0. As this limit is approached, responsiveness to selection will decline. The genotype $\times$ year variance was highly significant, but comparing selection differentials obtained by selecting $\mathrm{S}_{1}$ families on the basis of 1- and 2-yr data indicated that single-year evaluations would yield good selection gains. Finally, a selection program with $y=1, r=2$ should provide more genetic gain per year than a selection program with $y=2, r=1$.

\section{REFERENCES}

Call, J.W., J.E. Butcher, J.T. Blake, R.A. Smart, and J.L. Shupe. 1978. Phosphorus influence on growth and reproduction of beef cattle. J. Anim. Sci. 47:216-225.

Council for Agricultural Science and Technology. 2002. Animal diet modification to decrease the potential for nitrogen and phosphorus pollution. Issue paper no. 21, Ames, IA.

Duda, A.M., and D.S. Finan. 1983. Influence of livestock on nonpoint source nutrient levels of streams. Trans. ASAE 26:1710-1716.

Dudley, J.W., and R.J. Lambert. 1992. Ninety generations of selection for oil and protein in maize. Maydica 37:81-87.

EPA. 2002. Concentrated animal feeding operations-final rule [Online]. Available at http://cfpub.epa.gov/npdes/afo/cafofinalrule.cfm (posted 16 Dec. 2002; verified 6 Jan. 2003).

Erickson, G., T.J. Klopfenstein, T.C. Milton, D. Hanson, and C. Calkins. 1999. Effect of dietary phosphorus on finishing steer performance, bone status, and carcass maturity. J. Anim. Sci. 77:28322836.

Erickson, G.E., T.J. Klopfenstein, M.W. Orth, D. Brink, and K.M. Whittet. 2002. Phosphorus requirements of finishing steer calves. J. Anim. Sci. 80:1690-1695.

Ertl, D.S., K.A. Young, and V. Raboy. 1998. Plant genetic approaches to phosphorus management in agricultural production. J. Environ. Qual. 27:299-304.

Feil, B., R. Thiraporn, and P. Stamp. 1992. Can maize cultivars with low mineral nutrient concentrations in the grains help to reduce the need for fertilizers in third world countries? Plant Soil 146:227-231.

Littell, R.C., G.A. Milliken, W.W. Stroup, and R.D. Wolfinger. 1996. SAS system for mixed models. SAS Institute, Inc., Cary, NC.

Milton, T.C. 2000. Role of the grain processing industries on phosphorus feeding issues [Online]. Available at http://manure.unl.edu/ adobe/v6n8_00.pdf (verified 6 Jan. 2003).

Morse, D., H.H. Head, and C.J. Wilcox. 1992. Disappearance of phosphorus from concentrates in vitro and from rations fed to lactating dairy cows. J. Dairy Sci. 75:1979-1986.

National Research Council. 1996. Nutrient requirements of beef cattle. 7th ed. National Academy Press, Washington, DC.

Raboy, V.1997. Accumulation and storage of phosphate and minerals. p. 441-447. In B.A. Larkins and I.K. Vasil (ed.) Cellular and molecular biology of plant seed development. Kluwer Academic Publ., Dordrect, Netherlands.

Raboy, V., F.E. Below, and D.B. Dickinson. 1989. Alteration of maize kernel phytic acid levels by recurrent selection for protein and oil. J. Hered. 80:311-315.

SAS Institute Inc. 1999. SAS/STAT user's guide. Version 8. SAS Institute Inc., Cary, NC.

Vyn, T.J., and M. Tollenaar. 1998. Changes in chemical and physical quality parameters of maize grain during three decades of yield improvement. Field Crops Res. 59:135-140.

Wardyn, B.M. 2001. The genetic control of phosphorus concentration in maize grain. M.S. thesis. Univ. of Nebraska-Lincoln.

White, W.C., and D.N. Collins. (ed.) 1982. The Fertilizer Handbook. The Fertilizer Inst., Washington, DC.

Zehr, B.E., S.R. Eckhoff, W.E. Nyquist, and P.L. Keeling. 1996. Heritability of product fractions from wet milling and related properties of maize grain. Crop Sci. 36:1159-1165. 